\title{
HSCT FOR SOLID TUMORS
}

\author{
Leonardo Javier Arcuri ${ }^{1,2}$, Andreza Alice Feitosa Ribeiro ${ }^{1,2}$ e Décio Lerner ${ }^{1}$. \\ 1 Instituto Nacional de Cancer, Rio de Janeiro, Brazilb - 2Hospital Israelita Albert Einstein, São Paulo, Brazil
}

\section{INTRODUCTION}

High-dose chemotherapy (HDCT) with stem-cell support is a procedure that allows the administration of high doses of chemotherapy that would be lethal otherwise. In HDCT, extra-medullary toxicity is the dose-limiting factor. Use of peripheral blood stem cells and improvement in patient management has reduced non-relapse mortality to less than $5 \%$. Over the last decades, knowledge about HDCT in solid tumors has increased, particularly in breast, ovary, lung, and germ cell tumors (GCT ${ }^{[1-3]}$. Allogeneic hematopoietic stem-cell transplantation (HSCT) has also been explored, especially in advanced kidney cancer ${ }^{[3]}$.

\section{HIGH-DOSE CHEMOTHERAPY (HDCT) FOR GERM CELL TUMOR (GCT)}

Recommendation: HDCT should not be offered for frontline therapy in germ cell tumors (Level of Evidence 1b, Grade of Recommendation A).

Recommendation: HDCT should be offered as second or third-line therapy of germ cell tumor, even in patients with mediastinal, platinum-refractory, or non-seminomatous GCT (Level of Evidence 2b, Grade of Recommendation $B$ ).

Recommendation: Conditioning regimen should be carboplatin and etoposide (Level of Evidence 1b, Grade of Recommendation A).

Recommendation: Two or three cycles of HDCT should be offered instead of one (Level of Evidence 1b, Grade of Recommendation B).

Recommendation: For patients with residual disease following HDCT, surgical resection should be performed (Level of Evidence 4, Grade of Recommendation C).

Testicular malignant tumors are the most frequent solid tumor of the young male, and $95 \%$ of these are germ cell tumors (GCT) ${ }^{[4]}$. They are unique tumors in which they represent a malignant transformation of a totipotent germ cell. They are divided, histological- ly, in seminoma and nonseminoma. Both secrete beta-human chorionic gonadotropin (beta-HCG), while only the latter produces al pha-fetoprotein (AFP). Approximately $75 \%$ of the patients are cured with conventional5. Follow-up includes serial image exams and of the serum markers HCG e AFP.

\section{FRONTLINE HIGH-DOSE CHEMOTHERAPY}

Frontline HDCT is not recommended. There are four randomized trials (an Italian ${ }^{[6]}$, a French ${ }^{[7]}$, an American phase $\mathrm{III}^{[8]}$, and a European phase $\mathrm{III}^{[9]}$ ) that have not shown a benefit of HDCT in high-risk patients. In the American trial, however, there was a trend towards better response in patients with unsatisfactory tumor marker response (61\% CR with 1-y duration, against $34 \%, p=0.03$ ). A systematic review that included phase III and phase II trials showed no overall survival benefit in patients with unsatisfactory serum marker response ${ }^{[10]}$.

\section{RELAPSE AND REFRACTORY DISEASE}

A unique characteristic of germ cell tumor management is that conventional chemotherapy can cure relapsed patients. A large series is frequently cited for comparison ${ }^{[11]}$. In this series, relapsed and refractory patients were treated with vinblastine, ifosfamide, and cisplatin (VelP). Fifty percent reached a complete response, and $24 \%$ were long-term disease-free.

Diagnosis of relapsed/refractory disease is not always straightforward. Patients with residual disease and persistently high AFP or HCG markers frequently have irresectable viable cancer and should undergo chemotherapy instead of surgery. On the other hand, radiologic progression paradoxically associated with adequate decline of serum markers can occur with teratoma growth syndrome, which should not be interpreted as progression ${ }^{[12]}$. Teratoma is insensitive to chemotherapy, and residual lesions should be resected. Likewise, lung nodular lesions, especially subpleural, can be induced by bleomycin. Moreover, 
marijuana can lead to a rise in HCG, and a rise in luteinizing hormone secondary to hypogonadal status may interfere with the HCG test.

Patients whose diseases progress during frontline therapy or within 4 weeks of the last dose of chemotherapy (platinum-refractory) are a poor-prognosis group of patients. Patients with seminoma have a better prognosis, as well as those with testicular or retroperitoneum relapse. Patients with mediastinal disease are another group of poor prognosis. Patients with an incomplete response, who are platinum-refractory, or primary mediastinal site have less than $10 \%$ overall survival in 10 years ${ }^{[13,14]}$.

\section{HIGH-DOSE CHEMOTHERAPY IN RELAPSED/ REFRACTORY PATIENTS}

High-dose chemotherapy is the second-line treatment of choice in many institutions, despite the lack of positive randomized trials. The chemosensitivity of GCT, the marked dose-response effect, the extremally low incidence of bone marrow metastasis, and the young age of these patients make HCT very attractive.

First phase I and II studies, from Indiana University ${ }^{[15]}$ and the Eastern Cooperative Oncology Group ${ }^{[16]}$, have shown that $15-20 \%$ of patients with multiple relapses can be cured. In the Indiana series, all long-term surviving patients received two cycles of $\mathrm{HDCT}$, and $75 \%$ of the patients with partial remission achieved complete remission after the second cycle. These studies underline the importance of surgery in patients with residual disease following HDCT.

Subsequent studies focused on drug-dose escalation $^{[17]}$, establishing the maximal tolerated dose Carboplatin 2,100 mg/m2 and Etoposide 2,250 mg/ $\mathrm{m} 2$. Marked reduction of non-relapse mortality was achieved with peripheral blood stem-cells.

There is only one phase III trial of HDCT in relapsed $\mathrm{GCT}^{[18]}$. In this study, 280 patients were randomized to receive 4 cycles of conventional chemotherapy or 3 cycles followed by HDCT. There was no difference in disease-free or overall survival. This study has been criticized by the low power, the toxic conditioning regimen, and the one-HDCT cycle. A systematic review supports the need for at least 2 cycles of HDCT10.

The greatest evidence of benefit of HDCT comes from a registry study ${ }^{[19]}$, which included more than 1,500 patients and showed a lower risk of death in first-relapse patients who received HDCT ( $\mathrm{HR}=0.65$,
$95 \% \mathrm{Cl}$ 0.56-0.75). In subgroup analyses, nonseminoma and low-risk patients seemed to not benefit. These results were confirmed in a retrospective analysis of the German Testicular Cancer Study Group ${ }^{20}$. Moreover, this study shows that more than $70 \%$ of relapsed patients undergo HDCT in second-line therapy, making comparisons more difficult.

Currently, the best reported results are from the Indiana University ${ }^{[21]}$ and the Sloan-Kettering Cancer Center ${ }^{14}$.

The Indiana University ${ }^{[21,22]}$ performs two HDCT cycles with Carboplatin $2,100 \mathrm{mg} / \mathrm{m} 2$ and Etoposide $2,250 \mathrm{mg} / \mathrm{m} 2$ followed by oral etoposide maintenance. With a median follow-up of 40 months, progression-free survival was $40 \%$. Interestingly, half of the patients with platinum-refractory or third-line patients had an excellent response.

The Memorial Sloan-Kettering Cancer Center ${ }^{[14]}$ performs three cycles of HDCT with Carboplatin and Etoposide. 5-y overall survival was 52\%. Most patients were platinum-refractory. Long-term overall survival for patients with mediastinal disease was $24 \%$.

\section{CONDITIONING REGIMEN AND SEQUENTIAL THERAPY}

The role of sequential HDCT and the addition of a third drug have been studied.

The German Testicular Study Group ${ }^{[1,23]}$ compared one cycle of HDCT with three cycles. A third drug was added to the group that received one cycle, but the mortality was significantly higher (16 versus $4 \%$ ), and the study was halted.

Grossi et al ${ }^{[24]}$, in a prospective study that included all patients treated in Switzerland, have not found differences in outcomes between 2 or 3 cycles of HDCT, while 1 cycle seemed to yield inferior results. In subgroup analysis, the third cycle of HDCT seemed to benefit patients who achieved a complete response after the first cycle. DeFilipp ${ }^{25}$ also found no difference between 2 or 3 cycles of HDCT.

In a large registry study ${ }^{[19]}, 5-y$ overall survival was significantly higher in patients who received sequential HDCT $(61 \%$ versus $46 \%, p<0.001)$ and in those who received Carboplatin and Etoposide conditioning (62\%, against 35\% with +lfosfamide, $44 \%$ +Thiothepa, $56 \%$ +Cyclophosphamide, $\mathrm{p}<0.001$ ).

An EBMT registry study ${ }^{[26]}$ suggested that non-relapse mortality is lower with Carboplatin and 
Etoposide conditioning regimen for patients older than 40 years.

A systematic review ${ }^{[10]}$ suggests that at least two cycles of HDCT should be offered, and a single cycle should not be used.

An EBMT study ${ }^{[27]}$ showed that the rates of secondary malignancies are $4.2 \%$ (solid tumor) and $1.4 \%$ (hematologic malignancy).

\section{POST-HDCT RESIDUAL MASS}

Surgical resection of residual masses plays an important role, contributing to the cure. In a German retrospective analysis ${ }^{[28]}$, viable tumor cells were found in $46 \%$ of the patients, and event-free survival in 5 years was $38 \%$. In patients with viable cancer, there is no benefit in chemotherapy. Progression and relapse following HDCT have a dismal prognosis, and in the Indiana series ${ }^{[29]}$ only patients who received surgical treatment were alive.

\section{Graft product contamination}

Tumor cells can be identified in up to half of the apheresis-collected grafts, but its importance is unknown. Results are contradictory. In one of them, there was no difference between the groups ${ }^{[30]}$, in another all patients with detectable tumor cell relapsed $^{[31]}$, and in the third no patients with undetectable tumor relapsed ${ }^{[32]}$.

\section{HIGH-DOSE CHEMOTHERAPY FOR OTHER SOLID TUMORS}

Recommendation: HDCT should be offered for ovarian germ tumor or gestational trophoblastic tumor, chemorefractory (Level of Evidence 4, Grade of Recommendation C).

Recommendation: HDCT should not be offered to any kind of breast cancer (Level of Evidence 1a, Grade of Recommendation A).

Recommendation: HDCT should not be offered for ovary or lung cancer (Level of Evidence 2b, Grade of Recommendation $B$ ).

Recommendation: HDCT should be offered to patients with high-risk localized Ewing sarcoma (Level of Evidence 16 , Grade of Recommendation A). HDCT can be offered for relapsed Ewing sarcoma (Level of Evidence $2 a$, Grade of Recommendation B)

\section{High-dose chemotherapy in ovarian cancer}

HDCT was tested in refractory and chemosensitive ovarian cancer ${ }^{[33-38]}$. Despite initial response, short remission was documented, and no benefit was observed $^{[36-39]}$. For patients with relapsed ovarian germ cell tumors, HDCT can be curative ${ }^{[40,41]}$.

\section{High-dose chemotherapy in lung cancer}

Small cell lung cancer is an extremally chemo- and radio-sensitive disease, with response rates of $80 \%$. Few patients are cured however2. Results with HDCT were disappointing, and the procedure was abandoned ${ }^{[42,43]}$.

\section{High-dose chemotherapy in breast cancer}

The role of HDCT in breast cancer remains controversial despite more than 20 years of experience. Two meta-analyses of randomized trials ${ }^{[44,45]}$ have not found survival benefit in HDCT. Recently, in a subgroup analysis, Steenbruggen et al ${ }^{[46]}$ suggest there might be a benefit for patients with $10+$ positive lymph nodes or with triple-negative breast cancer. These results, however, must be confirmed in appropriately designed clinical trials.

High-dose chemotherapy for gestational trophoblastic neoplasia

Gestational trophoblastic disease is a heterogeneous group of diseases that arise from the abnormal proliferation of the placental trophoblast, i.e., of the fetal tissue. It includes, among others, choriocarcinoma, trophoblastic tumor, and invasive mole. Beta-HCG may be high. Case reports and case series reported cure with $\mathrm{HDCT}^{[47-50]}$.

\section{High-dose chemotherapy for Ewing sarcoma}

Overall survival of Ewing sarcoma patients with conventional therapy ranges between 9 and $41 \%$. Patients with high-risk localized disease benefited from frontline $\mathrm{HDCT}^{[51]}$. High-risk disease was defined as poor histologic response ( $\geq 10 \%$ viable cells), large tumor volume at diagnosis ( $\geq 200 \mathrm{~mL}$ ), or small tumors with poor radiologic response ( $<50 \%$ reduction). In patients with pulmonary metastases, no benefit was seen ${ }^{[52]}$. A systematic review of observational studies suggests that relapsed patients might benefit from $\mathrm{HDCT}^{[53]}$.

\section{Allogeneic stem cell transplantation in solid tumors}

Recommendation: There is no data to recommend allogeneic stem-cell transplantation in solid tumors in any setting. 
TABLE 1 - Selected conditioning regimens

\begin{tabular}{|c|c|c|c|c|}
\hline Institution & Carboplatin & Etoposide & Cyclophosphamide & \# Transplants \\
\hline $\begin{array}{l}\text { MSKCC14,54dose-intense } \\
\text { chemotherapy with paclitaxel } \\
\text { and ifosfamide followed by } \\
\text { carboplatin and etoposide } \\
\text { (TICE }\end{array}$ & $A \cup C=24$ & $1,200 \mathrm{mg} / \mathrm{m} 2$ & $x$ & 3 \\
\hline Indiana 16 * & $2,100 \mathrm{mg} / \mathrm{m} 2$ & $2,250 \mathrm{mg} / \mathrm{m} 2$ & $x$ & 2 \\
\hline MSKCC55 & $1,500 \mathrm{mg} / \mathrm{m} 2$ & $1,200 \mathrm{mg} / \mathrm{m} 2$ & $150 \mathrm{mg} / \mathrm{kg}$ & 2 \\
\hline \multirow[t]{2}{*}{ Germany56 } & $1,500 \mathrm{mg} / \mathrm{m} 2$ & $1,500 \mathrm{mg} / \mathrm{m} 2$ & $x$ & 3 \\
\hline & Cisplatin & Etoposide & Ifosfamide & \# Transplants \\
\hline $\begin{array}{l}\text { EORTC9etoposide, and } \\
\text { ifosfamide (VIP }\end{array}$ & $100 \mathrm{mg} / \mathrm{m} 2$ & $1,500 \mathrm{mg} / \mathrm{m} 2$ & $12,000 \mathrm{mg} / \mathrm{m} 2$ & 3 \\
\hline
\end{tabular}

*etoposide oral maintenance $50 \mathrm{mg} /$ day $\times 21$ days every 4 weeks for 3 cycles

TABLE 2 - High-dose chemotherapy in relapsed/refractory GCT patients

\begin{tabular}{|c|c|c|c|c|c|}
\hline Institution & \#Patients & CR & \%Alive and disease-free & Follow-up & TRM \\
\hline MSKCC55 & 58 & 40 & 21 & 28 months & $12 \%$ \\
\hline Indiana15 & 40 & 30 & 15 & $>24$ months & $18 \%$ \\
\hline $\begin{array}{l}\text { Germany } 57230 \text { patients were } \\
\text { planned to be recruited in } \\
\text { a prospective, randomized, } \\
\text { multicenter trial comparing } \\
\text { one cycle of cisplatin } 100 \mathrm{mg} / \\
\mathrm{m} 2 \text {, etoposide } 375 \mathrm{mg} / \mathrm{m} 2 \text {, and } \\
\text { ifosfamide } 6 \mathrm{~g} / \mathrm{m} 2(\mathrm{VIP}\end{array}$ & 74 & 50 & 38 & 48 months & $3 \%$ \\
\hline $\begin{array}{l}\text { MSKCC58which had been identified } \\
\text { previously as favorable prognostic } \\
\text { factors to conventional-dose } \\
\text { salvage chemotherapy.InRESULTS: } \\
\text { Thirty-two }(70 \%\end{array}$ & 84 & 56 & 50 & 58 months & NA \\
\hline Indiana21 & 184 & NA & 63 & 48 months & $3 \%$ \\
\hline ECOG16 & 38 & 24 & 13 & $>18$ months & $13 \%$ \\
\hline Europe18 & 109 & 26 & 31 & 45 months & $7 \%$ \\
\hline Germany59 & 176 & $15^{*}$ & 34 & $>60$ months & NA \\
\hline $\begin{array}{l}\text { Germany 28postchemotherapy } \\
\text { resections of residual tumors were } \\
\text { performed in } 57 \text { patients who } \\
\text { had been treated with HDCT for } \\
\text { relapsed or refractory GCT and who } \\
\text { had achieved a partial remission to } \\
\text { this treatment.InRESULTS: Complete } \\
\text { resections of residual masses were } \\
\text { achieved in } 52 \text { ( } 91 \%\end{array}$ & 211 & $22^{* *}$ & 43 & 36 months & $9 \%$ \\
\hline MSKCC14 & 107 & $42^{* * *}$ & 53 & $>60$ months & $2 \%$ \\
\hline
\end{tabular}

CR: complete remission; TRM: Transplant-related mortality. NA: Not available

* $38 \%$ in total, when included patients who underwent posttransplant surgical resection

** $37 \%$ in total, when included patients who underwent posttransplant surgical resection

*** $50 \%$ in total, when included patients who underwent posttransplant surgical resection 


\section{REFERENCES}

1.Pedrazzoli, P. et al. High-dose chemotherapy with autologous hematopoietic stem cell support for solid tumors in adults. Semin. Hematol; v. 44, p.286-295, 2007.

2.Banna, G. L., Simonelli, M. \& Santoro, A. Highdose chemotherapy followed by autologous hematopoietic stem-cell transplantation for the treatment of solid tumors in adults: a critical review. Curr Stem Cell Res Ther; v.2, p.65-82, 2007.

3.Nieto, Y., Jones, R. B. \& Shpall, E. J. Stem-cell transplantation for the treatment of advanced solid tumors. Springer Semin. Immunopathol. v.26, p. 36-56, 2004.

4.Bosl, G. J. \& Motzer, R. J. Testicular germ-cell cancer. N. Engl. J. Med; v. 337, p. 242-253, 1997.

5.Williams, S. D. et al. Treatment of disseminated germ-cell tumors with cisplatin, bleomycin, and either vinblastine or etoposide. N. Engl. J. Med; v. 316. p. 1435-1440, 1987.

6.Necchi, A. et al. High-dose sequential chemotherapy (HDS) versus PEB chemotherapy as firstline treatment of patients with poor prognosis germ-cell tumors: mature results of an Italian randomized phase II study. Ann. Oncol; v.26, p.167-172, 2015.

7.Droz, J.-P. et al. Failure of high-dose cyclophosphamide and etoposide combined with double-dose cisplatin and bone marrow support in patients with high-volume metastatic nonseminomatous germ-cell tumours: mature results of a randomised trial. Eur. Urol. p. 739-746, 2007.

8.Motzer, R. J. et al. Phase III randomized trial of conventional-dose chemotherapy with or without high-dose chemotherapy and autologous hematopoietic stem-cell rescue as first-line treatment for patients with poor-prognosis metastatic germ cell tumors. J. Clin. Oncol. v.25, p. 247-256, 2007.

9.Daugaard, G. et al. A randomized phase III study comparing standard dose BEP with sequential high-dose cisplatin, etoposide, and ifosfamide (VIP) plus stem-cell support in males with poor-prognosis germ-cell cancer. An intergroup study of EORTC, GTCSG, and Grupo Germinal (EORTC 30974). Ann. Oncol. v. 22, p. 1054-1061, 2011.

10.bin Riaz, I. et al. Role of one, two and three doses of high-dose chemotherapy with autologous transplantation in the treatment of high-risk or relapsed testicular cancer: a systematic review. Bone Marrow Transplant; v.53, p. 1242-1254, 2018.

11.Loehrer, P. J., Gonin, R., Nichols, C. R., Weathers, T. \& Einhorn, L. H. Vinblastine plus ifosfamide plus cisplatin as initial salvage therapy in recurrent germ cell tumor. J. Clin. Oncol; p. 2500-2504, 1998.

12.André, F. et al. The growing teratoma syndrome: results of therapy and long-term follow-up of 33 patients. Eur. J. Cancer; v.36, p. 1389-1394, 2000.

13.Suleiman, Y., Siddiqui, B. K., Brames, M. J., Abonour, R. \& Einhorn, L. H. Salvage therapy with highdose chemotherapy and peripheral blood stem cell transplant in patients with primary mediastinal nonseminomatous germ cell tumors. Biol. Blood Marrow Transplant. v.19, p. 161-163, 2013.

14.Feldman, D. R. et al. TI-CE high-dose chemotherapy for patients with previously treated germ cell tumors: results and prognostic factor analysis. J. Clin. Oncol.it. v. 28, p. 1706- 1713, 2010.

15.Beyer, J. et al. High-dose chemotherapy as salvage treatment in germ cell tumors: a multivariate analysis of prognostic variables. J. Clin. Oncol. v.14, p. 2638-2645, 1996.

16.Nichols, C. R. et al. High-dose carboplatin and etoposide with autologous bone marrow transplantation in refractory germ cell cancer: an Eastern Cooperative Oncology Group protocol. J. Clin. Oncol; v.10, p. 558-563, 1992.

17.Broun, E. R. et al. Dose escalation study of highdose carboplatin and etoposide with autologous bone marrow support in patients with recurrent and refractory germ cell tumors. Bone Marrow Transplant; it. v.16, p. 353-358, 1995.

18.Pico, J.-L. et al. A randomised trial of high-dose chemotherapy in the salvage treatment of patients failing first-line platinum chemotherapy for advanced germ cell tumours. Ann. Oncol; it. p. 1152-1159, 2005.

19.Lorch, A. et al. Conventional-dose versus highdose chemotherapy as first salvage treatment in male patients with metastatic germ cell tumors: evidence from a large international database. J. Clin. Oncol. v. 29, p. 2178-2184, 2011.

20.Berger, L. A. et al. First salvage treatment in patients with advanced germ cell cancer after cisplatin-based chemotherapy: analysis of a regis- 
try of the German Testicular Cancer Study Group (GTCSG). J. Cancer Res. Clin. Oncol. v.140, p. 12111220,2014 .

21.Einhorn, L. H. et al. High-dose chemotherapy and stem-cell rescue for metastatic germ-cell tumors. N. Engl. J. Med; v. 357, p. 340-348, 2007.

22.Adra, N. et al. High-Dose Chemotherapy and Autologous Peripheral-Blood Stem-Cell Transplantation for Relapsed Metastatic Germ Cell Tumors: The Indiana University Experience. Journal of Clinical Oncology. v. 35, p. 1096, $2017 .$.

23.Lorch, A. et al. Sequential versus single highdose chemotherapy in patients with relapsed or refractory germ cell tumors: long-term results of a prospective randomized trial. J. Clin. Oncol; v. 30, p. 800-805, 2012.

24.Gössi, F. et al. Comparison of three or fewer highdose chemotherapy cycles as salvage treatment in germ cell tumors in first relapse. Bone Marrow Transplant; 52. p. (2017).

25.DeFilipp, Z. et al. Comparable outcomes following two or three cycles of high-dose chemotherapy and autologous stem cell transplantation for patients with relapsed/refractory germ cell tumors. Bone Marrow Transplant. v.52, p. 334-336, 2017.

26.Necchi, A. et al. Administration of high-dose chemotherapy with stem cell support in patients 40 years of age or older with advanced germ cell tumours: a retrospective study from the European Society for Blood and Marrow Transplantation database. Bone Marrow Transplant; v.52, p. 1218-1220, 2017.

27.on behalf of the European Society for Blood and Marrow Transplantation, Cellular Therapy \& Immunobiology Working Party - Solid Tumor sub-committee et al. Secondary malignancies after high-dose chemotherapy in germ cell tumor patients: a 34-year retrospective study of the European Society for Blood and Marrow Transplantation (EBMT). Bone Marrow Transplant. v.53, p. $722-728,2018$.

28.Rick, O. et al. Residual tumor resection after high-dose chemotherapy in patients with relapsed or refractory germ cell cancer. J. Clin. Oncol; v. 22, p.3713-3719, 2004.

29.Porcu, P., Bhatia, S., Sharma, M. \& Einhorn, L. H. Results of Treatment After Relapse From High-Dose Chemotherapy in Germ Cell Tumors. Journal of Clinical Oncology; v. 18, p. 1181-1186, 2000.
30.Hildebrandt, $M$. et al. Detection of germ-cell tumor cells in peripheral blood progenitor cell harvests: impact on clinical outcome. Clin. Cancer Res; v. 6, p. 4641-4646, 2000.

31.Bokemeyer, C. et al. Clinical impact of germ cell tumor cells in apheresis products of patients receiving high-dose chemotherapy. J. Clin. Oncol; v.19, n.3029-3036, 2001.

32.Hara, l. et al. Detection of beta-human chorionic gonadotropin expressing cells by nested reverse transcriptase-polymerase chain reaction in the peripheral blood stem cells of patients with advanced germ cell tumor. J. Urol; it. v.167, p. 14871491, 2002.

33.Cannistra, S. A. Cancer of the ovary. N. Engl. J. Med; v. 351, p. (2004).

34.McGuire, W. P. High-dose chemotherapeutic approaches to ovarian cancer management. Semin. Oncol; v. 27, p 2000.

35.Papadimitriou, C. et al. High-dose melphalan and autologous stem cell transplantation as consolidation treatment in patients with chemosensitive ovarian cancer: results of a single-institution randomized trial. Bone Marrow Transplant; v.41, p. 547-554, 2008.

36.Salerno, M. G. et al. High-dose chemotherapy as a consolidation approach in advanced ovarian cancer: long-term results. Bone Marrow Transplant; v.27, p. 1017-1025, 2001.

37.Bengala, C. et al. High-dose chemotherapy with autologous haemopoietic support for advanced ovarian cancer in first complete remission: retrospective analysis from the Solid Tumour Registry of the European Group for Blood and Marrow Transplantation (EBMT). Bone Marrow Transplant; v. 36, p. 25-31, 2005.

38.Lotz, J. P. et al. Tandem high-dose chemotherapy with ifosfamide, carboplatin, and teniposide with autologous bone marrow transplantation for the treatment of poor prognosis common epithelial ovarian carcinoma. Cancer; v. 77, p. 2550-2559, 1996.

39.Grénman, S. et al. A randomised phase III study comparing high-dose chemotherapy to conventionally dosed chemotherapy for stage III ovarian cancer: the Finnish Ovarian Cancer (FINOVA) study. Eur. J. Cancer; v.42, p. 2196-2199, 2006.

40.Reddy Ammakkanavar, N., Matei, D., Abonour, 
R. \& Einhorn, L. H. High-dose chemotherapy for recurrent ovarian germ cell tumors. J. Clin. Oncol; v.33, p. 226-227, 2015.

41.De Giorgi, U. et al. Salvage high-dose chemotherapy in female patients with relapsed/refractory germ-cell tumors: a retrospective analysis of the European Group for Blood and Marrow Transplantation (EBMT). Annals of Oncology; v.28, p. 1910-1916, 2017.

42.Pasini, F., Pelosi, G., De Manzoni, G. \& Rosti, G. High-dose chemotherapy in small cell lung cancer. Tumori; v. 88, p. 179-186, 2002.

43.Pedrazzoli, P. et al. High dose chemotherapy with autologous hematopoietic stem cell support for solid tumors other than breast cancer in adults. Ann. Oncol; v. 17, p. 1479-1488, 2006.

44.Berry, D. A. et al. High-dose chemotherapy with autologous stem-cell support as adjuvant therapy in breast cancer: overview of 15 randomized trials. J. Clin. Oncol; v. 29, p. 3214-3223, 2011.

45.Farquhar, C., Marjoribanks, J., Lethaby, A. \& Azhar, M. High-dose chemotherapy and autologous bone marrow or stem cell transplantation versus conventional chemotherapy for women with early poor prognosis breast cancer. Cochrane Database of Systematic Reviews 2016 doi:10.1002/14651858.CD003139.pub3.

46.Steenbruggen, T. G. et al. High-Dose Chemotherapy With Hematopoietic Stem Cell Transplant in Patients With High-Risk Breast Cancer and 4 or More Involved Axillary Lymph Nodes: 20-Year Follow-up of a Phase 3 Randomized Clinical Trial. JAMA Oncol v.6, p.528, 2020.

47.Benigno, B. B. High-dose chemotherapy with autologous stem cell support as salvage therapy in recurrent gestational trophoblastic disease. Int. J. Gynecol. Cancer 23, p. 1331-1333, 2013.

48.El-Helw, L. M. et al. High-dose chemotherapy and peripheral blood stem cell support in refractory gestational trophoblastic neoplasia. $\mathrm{Br}$. J. Cancer. v.93, p. 620-621, 2005..

49.Markman, M. Experience with platinum-based and high-dose chemotherapy in patients with gestational trophoblastic disease: possible implications for future management. J. Cancer Res. Clin. Oncol. v.130, p. 383-387, 2004.

50.Frijstein, M. M. et al. The results of treatment with high-dose chemotherapy and peripheral blood stem cell support for gestational tropho- blastic neoplasia. European Journal of Cancer; v. 109, p. 162-171, 2019.

51.Whelan, J. et al. High-Dose Chemotherapy and Blood Autologous Stem-Cell Rescue Compared With Standard Chemotherapy in Localized HighRisk Ewing Sarcoma: Results of Euro-E.W.I.N.G.99 and Ewingv 2008. v.36, p. 3110-3119, 2018.

52.Dirksen, U. et al. High-Dose Chemotherapy Compared With Standard Chemotherapy and Lung Radiation in Ewing Sarcoma With Pulmonary Metastases: Results of the European Ewing Tumour Working Initiative of National Groups, 99 Trial and EWING 2008. JCO; v.37, p. 3192-3202, 2019.

53.Tenneti, P. et al. Role of High-Dose Chemotherapy and Autologous Hematopoietic Cell Transplantation for Children and Young Adults with Relapsed Ewing's Sarcoma: A Systematic Review. Sarcoma; p. 1-12, 2018.

54.Kondagunta, G. V. et al. Paclitaxel plus Ifosfamide followed by high-dose carboplatin plus etoposide in previously treated germ cell tumors. J. Clin. Oncol; v.25, p. 85-90, 2007.

55.Motzer, R. J. et al. High-dose carboplatin, etoposide, and cyclophosphamide for patients with refractory germ cell tumors: treatment results and prognostic factors for survival and toxicity. J. Clin. Oncol; v. 14, p. 1098-1105, 1996.

56.Broun, E. R. et al. Long-term outcome of patients with relapsed and refractory germ cell tumors treated with high-dose chemotherapy and autologous bone marrow rescue. Ann. Intern. Med; v. 117, p. 124-128, 1992.

57.Lorch, A. et al. Single versus sequential highdose chemotherapy in patients with relapsed or refractory germ cell tumors: a prospective randomized multicenter trial of the German Testicular Cancer Study Group. J. Clin. Oncol ; v. 25, p.2778-2784, 2007..

58.Kondagunta, G. V. et al. Combination of paclitaxel, ifosfamide, and cisplatin is an effective second-line therapy for patients with relapsed testicular germ cell tumors. J. Clin. Oncol; v. 23, p. 6549-6555, 2005.

59.Sammler, C., Beyer, J., Bokemeyer, C., Hartmann, J.T. \& Rick, O. Risk factors in germ cell tumour patients with relapse or progressive disease after first-line chemotherapy: evaluation of a prognostic score for survival after high-dose chemotherapy. Eur. J. Cancer. 